\title{
1. Introduction: resolving the disputes on the basis of peace, justice and international cooperation
}

Japan has three long-festering territorial and maritime disputes with its three closest neighbors, China, ${ }^{1}$ Korea $^{2}$ and the Russian Federation (see Figure 1.1). The three disputes have very different origins and are unrelated to one another. However, they have in common the fact that they are leftover remnants of Japan's conflicts with neighboring countries during the last 150 years. They are rooted in history as well as contemporary power politics. During most of the post-war period - the last 63 years - Japan, as well as the other countries involved, chose to de-emphasize or ignore the matters involved in order to concentrate on more pressing priorities, such as economic development. The disputes in question involve relatively small pieces of territory and ocean space. In the last ten years or so, however, the disputes have become bound up with economic development and the national interests of the disputants, especially Japan. As a result, these disputes have become more dangerous and can no longer be ignored or "swept under the rug."

All three disputes have in common that they involve small islands and their surrounding maritime zones (see Figure 1.2). The three are as follows:

- The disputes with China involve legal title to the Senkaku (Diaoyu) Islands and the maritime delimitation of the East China Sea; an unrelated dispute concerns the status of the Japanese island of Okinotorishima in the Pacific Ocean.

- The dispute with Korea concerns legal title to the Takeshima (Dok/Dokdo/Tokdo) Islands and the maritime delimitation in the Japan Sea (East Sea).

- The dispute with Russia involves four disputed islands (known in Japan as the Northern Territories) north of Hokkaido, seized by the Soviet Union in 1945 at the end of World War II, as well as the surrounding maritime zones and maritime delimitation in this area. 


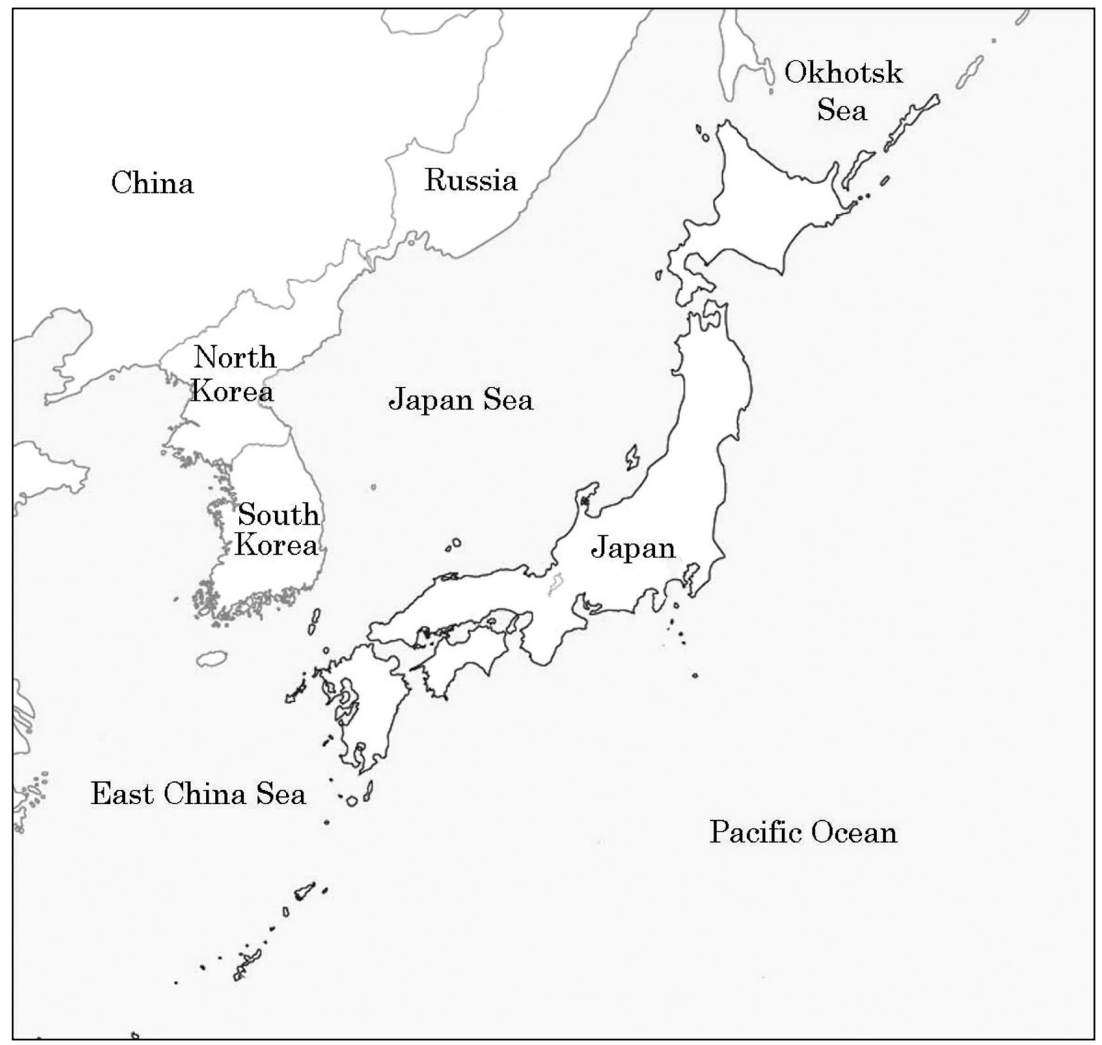

Figure 1.1 Japan and neighboring countries

In 2007, Japan passed important legislation to assert its rights and to protect its interests in the maritime zone-known as the Exclusive Economic Zone (EEZ) - that it controls under the UN Convention on the Law of the Sea (UNCLOS). Japan also created a new cabinet minister in charge of maritime affairs and policies. This new assertiveness increases the potential for conflict with neighboring countries because the maritime boundaries of Japan are not settled.

The purpose of the series of essays in this volume is to set out the history and basis of all three disputes and to suggest concrete ways they may be resolved. An additional purpose of this work is to demonstrate how international law and international institutions can provide the basis for peaceful and harmonious settlement of sometimes dangerous international disputes. All too often, in ancient as well as recent history, states and individuals have resorted to violence and war as a means of dealing with international 


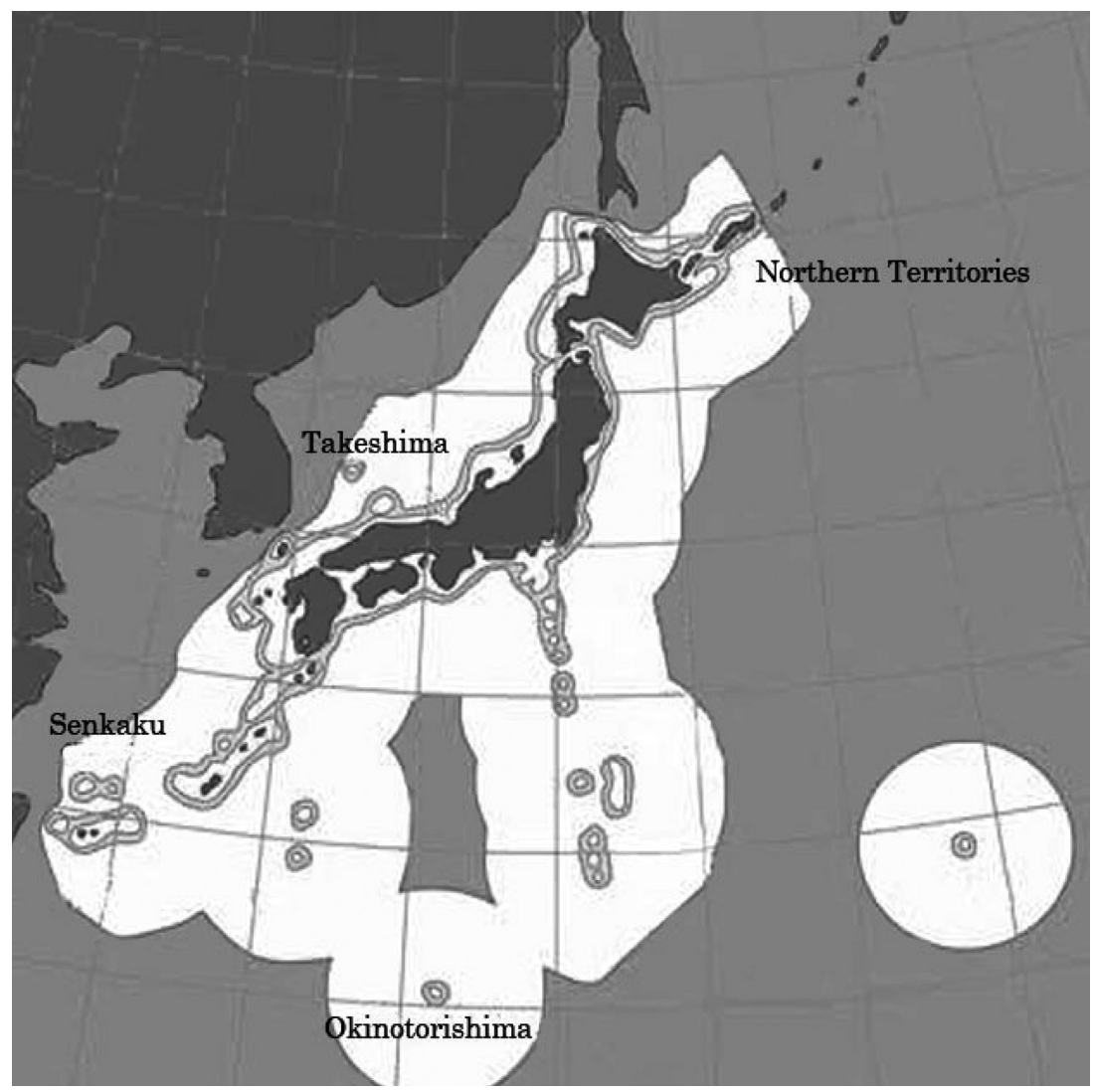

Figure 1.2 Japan's claimed maritime zones

problems. This is no longer acceptable, and in fact, resort to war is now prohibited by the United Nations Charter (Article 2, paragraph 4). The United Nations Charter, Article 33, further provides a series of methods for the peaceful resolution of disputes that are likely to endanger international peace.

Nevertheless, although most states and statesmen and stateswomen pay lip service to the principles of the United Nations Charter (adopted 26 June 1945), we see that in practice, states and their leaders often resort to the tired old game of emphasizing the necessity of asserting state interests and power to deal with any problems they may have with other countries. This way of dealing with international problems, known as "realism" (which comes in many varieties, such as classical [unalloyed] realism and "neorealism"), does, however, make an occasional bow in the direction of international institutions. 
A purpose of this book is to deride the idea that disputes, such as the ones that Japan has with its closest neighbors, can be successfully dealt with by realism and the assertion of state interests and power by the states concerned. Such a course will only result in disaster. Thankfully, the disputes in question have not (yet) been treated with the medicine of realism, and peace has mainly prevailed, despite a few nasty incidents. Instead, the states concerned have mainly chosen to de-emphasize or even ignore the disputes, choosing to move on to more interesting and promising matters, such as increasing economic ties. This course of action (or inaction) preserves the peace, although uneasily, and is therefore superior to outright realism. But an even better course is to use international law and institutions, including recognized methods of dispute settlement, to confront and permanently resolve the disputes. This is the course urged by this book.

Using international law and legal methods of dispute settlement is not now favored in the world. In another book (Chiba and Schoenbaum, 2008) I have referred to this method as "the path not taken." In the current volume, I would accordingly like to demonstrate the utility of the international law approach by applying it to the concrete problem of maintaining (some would say establishing) peace in Northeast Asia.

This book espouses three guiding principles in proposing solutions to the three disputes. First, the disputes must be resolved peaceably. This is fundamental because the peaceful resolution of disputes is enshrined in Article 33 of the United Nations Charter, to which all the disputants belong and have subscribed. Accordingly, the threat or the use of force by any state must under no circumstance be brought to bear on the disputes.

Second, the disputes must be settled justly and fairly. Since the disputants are sovereign states, this means that international law should be an important basis for the settlement of the disputes. Only through adherence to principles of international law can justice be served for all sides in these matters.

Third, international cooperation between the participants is an important principle that must be served if the solutions found are to be permanent ones rather than simply preludes to new conflicts. International cooperation between Japan and its neighbors is also long overdue. Unlike Europe, the other major theater of World War II, Northeast Asia has not developed multilateral and cooperative institutions to deal with contemporary problems. Fostering international cooperation to end the three disputes would arguably not only end the disputes themselves, but would start a needed path of ever-broader cooperative effort to bring peace, prosperity and lasting goodwill among the peoples of Northeast Asia. The principle of international cooperation has the potential of turning the disputes from negative and disruptive irritations into sources of international harmony 
and friendship. A negative factor can be turned into a positive influence for the future of all four countries. Thus, I will propose not a one-time solution to each dispute, but a continuing process of cooperation. Only a continuing process of international cooperation can truly keep the peace.

The key recommendation of this book is to propose that the three disputes in question be resolved through the conclusion of three separate negotiated agreements between Japan and each of its neighbors, whereby three separate Zones of Cooperation and Environmental Protection will be established in Northeast Asia. These three agreements would be international treaties with the purpose of establishing ongoing permanent cooperation in the three disputed areas. In addition, broader multilateral institutions of cooperation are needed, a matter addressed in the concluding Chapter 8.

After this Introduction, the second chapter of this book, by Professor Reinhard Drifte, will set out in detail the political background of the most dangerous of the three disputes, the East China Sea dispute between Japan and China. Professor Drifte's account shows that intensive discussion has been ongoing, but, for various reasons, has not yielded any concrete solutions. Both sides, however, have exercised admirable restraint, and their interest in a cooperative settlement is apparent. The stage is seemingly set for such a solution.

Chapter 3 of this book, by the editor, Thomas J. Schoenbaum, details the legal background and the international law arguments of the three disputes. This chapter also evaluates the legal positions of the disputants concerning the issues involved and explores how international law can provide the basis for solutions to all three disputes.

Chapter 4, by Professor Michael Hahn, explores the options that the parties have for peaceful settlement of the disputes. These options are very great: the parties can negotiate settlements in bilateral discussions; they can also choose to involve a third party as mediator or good offices facilitator. A third option is international arbitration to settle the differences. Fourth, the parties could submit the disputes to an international tribunal for a judicial proceeding and result. Both the UN Tribunal for the Law of the Sea and the International Court of Justice may be utilized for this purpose. Thus, the options for peaceful resolution of the disputes are many. Thus far, only bilateral discussions have occurred between the parties to the disputes. Perhaps it is now time to try additional options. The solutions proposed herein may be appropriate as suggestions for bilateral resolution of the claims involved, but may be easier to accept if a third-party dispute settlement option were to be utilized.

The next three chapters are detailed proposals for how the three disputes should best be resolved, keeping in mind the three criteria of (1) peace; 
(2) justice; and (3) international cooperation. Chapter 5 proposes solutions for all three disputes Japan has with China; Chapter 6 proposes solutions to the disputes with South Korea; and Chapter 7 proposes a solution to the Northern Territories dispute with the Russian Federation. All these chapters are authored by the editor, Thomas J. Schoenbaum.

The final chapter, also by Thomas J. Schoenbaum, proposes the creation of two new international institutions as permanent security architecture for Northeast Asia: an Organization for Peace and Security Cooperation and an East Asian Economic Community.

\section{NOTES}

1. Technically the dispute is also with Taiwan, but for practical purposes, the People's Republic of China is the only disputant involved.

2. This dispute is also potentially with North Korea as well as South Korea, but only the latter is really involved.

\section{REFERENCE}

Chiba, S. and T.J. Schoenbaum (eds) (2008), Peace Movements and Pacifism After September 11, Cheltenham, UK and Northampton, MA, USA: Edward Elgar. 